\title{
Taxonomic, Phylogenetic, and Functional Diversity of Ferns at Three Differently Disturbed Sites in Longnan County, China
}

\author{
Xiaohua Dai ${ }^{1,2, * \mathbb{D}}$, Chunfa Chen ${ }^{1}$, Zhongyang $\mathrm{Li}^{1}$ and Xuexiong Wang ${ }^{1}$ \\ 1 Leafminer Group, School of Life Sciences, Gannan Normal University, Ganzhou 341000, China; \\ ccf19960309@163.com (C.C.); lizy1983@gmail.com (Z.L.); wangxuexiong2004@163.com (X.W.) \\ 2 National Navel-Orange Engineering Research Center, Ganzhou 341000, China \\ * Correspondence: xiaohuadai@gnnu.edu.cn or ecoinformatics@gmail.com; Tel.: +86-137-6398-8183
}

Received: 16 March 2020; Accepted: 30 March 2020; Published: 1 April 2020

check for updates

\begin{abstract}
Human disturbances are greatly threatening to the biodiversity of vascular plants. Compared to seed plants, the diversity patterns of ferns have been poorly studied along disturbance gradients, including aspects of their taxonomic, phylogenetic, and functional diversity. Longnan County, a biodiversity hotspot in the subtropical zone in South China, was selected to obtain a more thorough picture of the fern-disturbance relationship, in particular, the taxonomic, phylogenetic, and functional diversity of ferns at different levels of disturbance. In 90 sample plots of $5 \times 5 \mathrm{~m}^{2}$ along roadsides at three sites, we recorded a total of 20 families, 50 genera, and 99 species of ferns, as well as 9759 individual ferns. The sample coverage curve indicated that the sampling effort was sufficient for biodiversity analysis. In general, the taxonomic, phylogenetic, and functional diversity measured by Hill numbers of order $q=0-3$ indicated that the fern diversity in Longnan County was largely influenced by the level of human disturbance, which supports the 'increasing disturbance hypothesis'. Many functional traits of ferns at the most disturbed site were adaptive to the disturbance. There were also some indicators of fern species responding to the different disturbance levels. Hence, ferns may be considered as a good indicator group for environmental stress.
\end{abstract}

Keywords: phylogenetic diversity; functional diversity; Hill numbers; increasing disturbance hypothesis; indicator species analysis

\section{Introduction}

Ferns are the second most diverse group among vascular plants with approximately 11,000 species [1-3]. Ferns are distributed globally, but they have the highest density in the tropical mountains [4]. Ferns are sensitive to the indicators of environmental conditions [5-10], with various adaptative strategies to variations in climatic and edaphic parameters [11,12]. Hence, fern diversity shows clear patterns along environmental gradients at different spatial scales $[8,13,14]$.

In contrast to many other groups of plants and animals, the taxonomic diversity of fern gradients generally follows a hump-shaped unimodal pattern along the elevational gradient $[4,9,10,15-30]$. The main drivers for such unimodal patterns are the combined effects of different climatic factors, including the temperature, precipitation, and cloud cover [4,8-10,21,27-35]. Generally, fern diversity tends to be high in temperate and humid habitats but low in cold, hot, and arid habitats $[10,36]$. The elevational range in a region and the macroevolutional history of specific fern groups are essential to the development of the latitudinal diversity pattern of ferns [25,32,37]. Human activities, environmental heterogeneity, soil, and topography also affect fern diversity at different elevations $[8,23,34,38,39]$. Researchers have argued that geometrical constraints, such as the mid-domain and area effects, might 
help to explain the hump-shaped patterns $[9,22,26,36,40]$. Another cause of diversity patterns is that different fern groups show different latitudinal and elevational diversity patterns [24,35,39,41]. For example, the richness of terrestrial xerophytic ferns often decreases with elevation; whereas, the richness of epiphytic ferns and terrestrial hygrophytic ferns generally increase with elevation $[24,41]$.

At the local (habitat) scale, fern diversity is often controlled by light, moisture, soil, and topographic conditions [42-48]. For instance, high canopy openness may increase light but reduce moisture and thus decrease the ground fern diversity [49]. In a study in Uganda, both the soil fertility and distance to the nearest Pleistocene forest refugium could explain most of the variance in fern diversity [14]. Fern diversity also depends on the topography, and is typically higher on the slopes than on ridges [50]. In South China, fern diversity is higher on the east- and north-facing slopes than it is on the west- and south-facing slopes [51]. In contrast, slopes affect species composition but not the species richness of ferns and lycophytes in tropical Brazil [52]. Finally, interspecific interactions, and especially competition, also contribute to the local diversity of ferns [4,42]. Strong correlations have also been found between epiphyte fern diversity and body size, plant height, height below twigs, and species composition of their phorophytes [53].

In the age of Anthropocene, human impacts have significantly changed the whole biosphere and are threatening ecosystems and biodiversity worldwide [54]. The distribution, diversity, and dynamics of fern assemblages are profoundly affected by human disturbances $[8,12,15,55-65]$. Disturbances might modify the external conditions and interspecific interactions to lead to changes in the fern assemblages $[15,66]$. However, compared to seed plants, the diversity patterns of ferns along a disturbance gradient are much less studied [61-63], let alone the mechanisms behind the patterns $[38,46,62]$. There are several possible patterns of the fern diversity-disturbance relationship: (1) the "intermediate disturbance hypothesis" proposes that the highest diversity occurs at moderate disturbance levels [67]; (2) the "increasing disturbance hypothesis" (i.e., increased disturbance hypothesis or environmental stress hypothesis) states that diversity decreases when disturbances increase [68]; (3) the "habitat specialist hypothesis" assumes that the highest diversity of habitat specialists occurs at less disturbed sites [69]; (4) whereas the "opportunistic species hypothesis" claims that the dominance of the generalist (opportunistic) group increases in disturbed areas [68].

Biodiversity can be described using indicators at different levels, often focusing on composition (taxonomic diversity), but also taking into account the functional relationships in the ecosystem (functional diversity) and even the regional evolutionary history (phylogenetic diversity) [33,70]. There is no single method that can reflect the overall pattern of biodiversity, and each diversity metric reveals different aspects of the overall diversity [33]. Accordingly, different diversity measurements do not always show consistent patterns with each other $[12,33,70,71]$. The reinterpretation of diversity around the Hill numbers [72] is a powerful tool for unifying the comparisons between habitats and scales [73-78]. Therefore, it is better to select multiple diversity elements together to evaluate overall fern biodiversity $[12,71,79,80]$.

Compared to angiosperms, studies on the phylogenetic and functional diversity of ferns along the environmental and disturbance gradients are much fewer [12,33,70,71,79-83]. For example, the phylogenetic diversity of Neotropical ferns increases significantly with decreasing soil fertility [82]. The phylogenetic diversity of ferns has no noticeable elevational trend in either Central Japan [70] or Central America [71]. The functional diversity of ferns in Central Japan is overdispersed at lower elevations but clustered at higher elevations, suggesting competitive interactions at low elevations and environmental filtering at high elevations [70]. The functional diversity of epiphytes in Central America [71] and of ferns and lycophytes in Mexico [12] is the highest at intermediate elevations, which has been interpreted as environmental filtering at low and high elevations. However, the functional diversity of ferns and lycophytes shows no general relationship with habitat disturbances [12].

In summary, the overall diversity of ferns along the disturbance gradient is still poorly known and requires further study. In our study, we set out to address the following issues: (1) to contribute to 
a more thorough picture of the fern-disturbance relationship and (2) assess the Hill number-based taxonomic, phylogenetic, and functional diversity of ferns at different levels of disturbance.

\section{Materials and Methods}

\subsection{Study Sites}

Longnan County $\left(24.91^{\circ} \mathrm{N}, 114.79^{\circ} \mathrm{E}\right)$ is located in South China, with a subtropical monsoon climate and with an elevational range of 190-1430 m a.s.l. We selected three study sites (Figure 1; Table 1) to carry out fern investigations. The distance between the three sites is approximately 65 km (Jiulianshan National Nature Reserve (JLS) to Leigongshan Family Farm (LGS)), 37 km (JLS to Anjishan Provincial Forest Park (AJS)), and $33 \mathrm{~km}$ (AJS to LGS). The annual rainfalls of the three sites fall in the isohyet of 1500-1600 mm, while their mean temperatures in January and July fall in the isotherm of $8{ }^{\circ} \mathrm{C}$ and $28^{\circ} \mathrm{C}$, respectively [84]. According to the maps of the U.S. Geological Survey, the generalized geologic ages of all three sites are Paleozoic/Precambrian (PzpCm) [85]. Detailed descriptions of Longnan County and the three sites were provided in our previous studies [86-89].

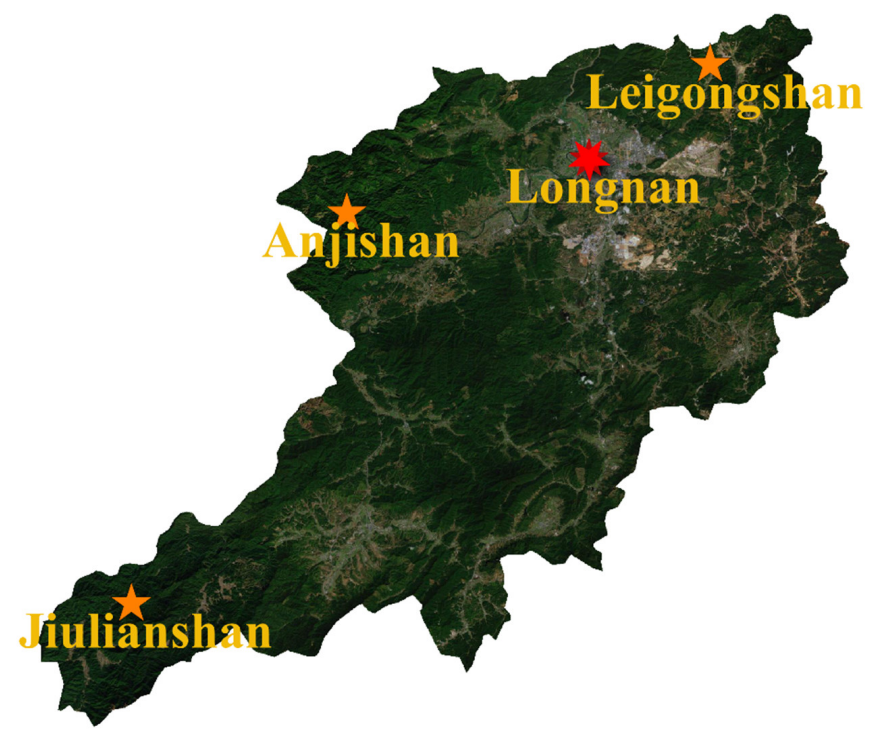

Figure 1. The locations of three study sites in Longnan County, China. The imagery data of Longnan County were obtained from Map World (http://www.tianditu.gov.cn) and produced with QGIS 3.8 [90].

Table 1. The information of three study sites in Longnan County, China.

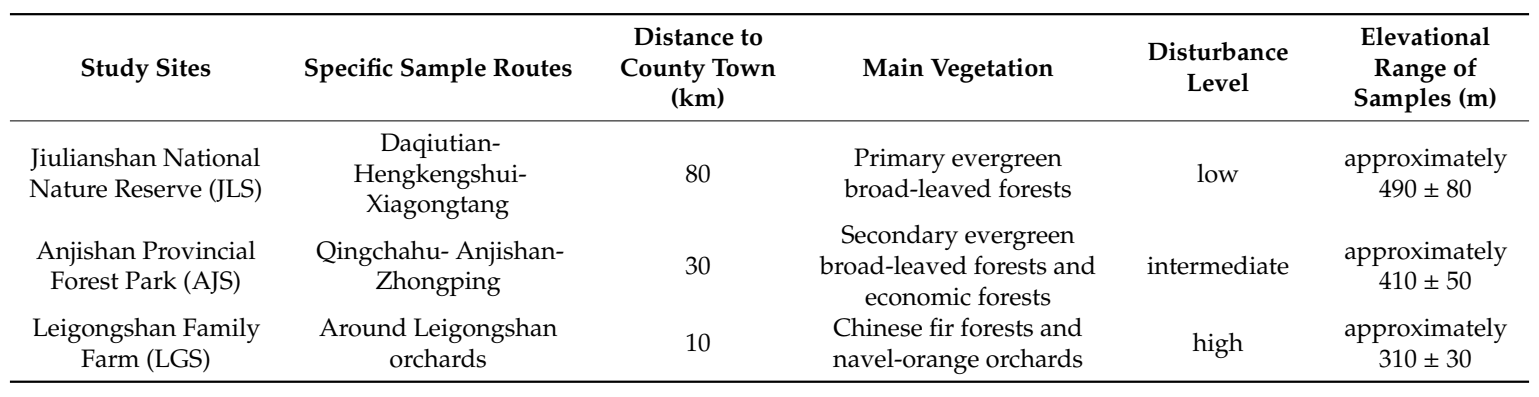

\subsection{Sampling Techniques}

We chose typical roads/trails across the dominant vegetation type of each site for fern investigation. At each study site, we placed 30 sampling plots in suitable habitats at the roadsides. There were a total of 90 plots in our study. Each plot was $5 \mathrm{~m} \times 5 \mathrm{~m}$, as in some previous local-scale practices [48,51,52,91,92], which is suitable for roadside sampling, especially for the managed forests and orchards at LGS. The 
distances between every two plots were all above $600 \mathrm{~m}$. We covered large areas and thus encountered more fern species at each site. For the analyses, we treated all 30 plots at each site as one assemblage.

We identified and counted all the ferns in each plot. The undetermined fern species were marked and taken back to the laboratory for further identification using keys. As lycophytes are not ferns [93], we excluded them from our analyses. Fern species names were verified with the R package 'plantlist' [94].

\subsection{Data Analyses}

We used the number of individuals for every fern species in an assemblage to calculate the following diversity indices:

(1) Based on the assemblage datasets (Table S1), taxon richness were computed with Microsoft Excel 2016.

(2) At present, we do not have the molecular sequences of all fern species and could not build a species-resolution phylogenetic tree. Therefore, we generated a genus-resolution phylogenetic tree (Figure S1, File S1) with the R package 'V.PhyloMaker' using the 74,533-species mega-tree GBOTB.extended.tre, which covers all families in extant vascular plants [95]. The mega-tree is updated from two recent mega-trees $[96,97]$, with the function to bind the undetermined species to their close relatives in the phylogenetic tree [95]. Phylogenetic diversity indices were calculated with the $R$ package 'picante' [98].

(3) We extracted the fern traits (Table S2) from publications and websites. We took into account 17 traits, including the maximum lamina length, maximum lamina width, petiole length, frond heterophylly, lamina texture, leaf arrangement, rhizome type, rhizome position, lamina dissection, lamina shape, sori shape, sori position, indusia, reproduction type, phenology, habit and scales/hair density $[12,70,71]$, to calculate the functional distances between species and hence the functional diversity of the three assemblages. For the quantitative traits, we used the measured values directly; for the presence/absence traits, we assigned 1-0 values; and we quantified qualitative traits with biological/ecological ranks(Table S2). The summary statistics, including the mean, median, minimum, maximum, and standard deviation of each trait value, are listed in Table S2. The functional diversity indices were obtained with the R package 'FD' [99].

(4) Taxonomic, phylogenetic, and functional diversity through Hill numbers $(q)$ are unified standardization methods to quantify the diversity of different communities [73-78]. The equivalent diversity indices linked to Hill numbers of order $q=0,1,2$ are listed in Table 2. In every case, we performed these analyses with the R package 'hillR' [100].

Table 2. The equivalent diversity indices linked to Hill numbers of order $q=0,1,2$.

\begin{tabular}{|c|c|c|c|c|c|}
\hline $\begin{array}{c}\text { Diversity } \\
\text { Component }\end{array}$ & Hill Number Series & $\begin{array}{l}\text { All Species } \\
(q=0)\end{array}$ & $\begin{array}{c}\text { Common } \\
\text { Species }(q=1)\end{array}$ & $\begin{array}{c}\text { Dominant } \\
\text { Species }(q=2)\end{array}$ & References \\
\hline $\begin{array}{l}\text { taxonomic } \\
\text { diversity }\end{array}$ & $\begin{array}{l}\text { the effective number of species } \\
\qquad{ }^{q} T D=\left(\sum_{i=1}^{S} p_{i}^{q}\right)^{1 /(1-q)}\end{array}$ & $S$ & $e^{H}$ & $1 / \lambda$ & {$[73,74,101,102]$} \\
\hline $\begin{array}{l}\text { phylogenetic } \\
\text { diversity }\end{array}$ & $\begin{array}{l}\text { the effective total phylogenetic distance } \\
\text { between species } \\
\qquad{ }^{q} P D=\frac{1}{T}\left[\sum_{i \in B_{T}} L_{i}\left(\frac{a_{i}}{T}\right)^{q}\right]^{1 /(1-q)}\end{array}$ & $F P D / T$ & $e^{A / T}$ & $1 /(1-Q / T)$ & {$[73,103]$} \\
\hline $\begin{array}{l}\text { functional diversity } \\
\qquad\end{array}$ & $\begin{array}{l}\text { the effective total functional distance } \\
\text { between species } \\
{ }^{q} F D=\left[\sum_{i=1}^{S} \sum_{j=1}^{S} d_{i j}\left(\frac{p_{i} p_{j}}{Q}\right)^{q}\right]^{1 /(1-q)}\end{array}$ & $F A D$ & - & $\frac{Q^{2}}{Q-G S}$ & [101,104-106] \\
\hline
\end{tabular}

@ $p_{i}=$ the relative abundance of the $i$ th species; $S=$ the number of species (i.e., species richness); $H=$ Shannon's entropy; $\lambda=$ Simpson's dominance index $[73,74,101,102]$. \# $T=$ the age of the root node of the ultrametric phylogenetic tree; $B_{T}=$ the set of all branches in the time interval $[-T, 0] ; L_{i}=$ the length of the $i$ th branch; $a_{i}=$ the total abundance descended from the $i$ th branch; $F P D=$ Faith's phylogenetic diversity; $A$ = Allen's phylogenetic entropy; $Q=$ Rao's quadratic entropy; the corresponding equations and the equivalent diversity indices for taxonomic classification and nonultrametric phylogenetic tree can refer to $[73,103] . \$ d_{i j}=$ the functional distance between the species pair $(i, j) ; p_{i} p_{j}=$ join probability for the species pair $(i, j) ; S=$ the number of species; $Q=$ Rao's quadratic entropy; $F A D=$ Functional attribute diversity; $G S=$ the weighted Gini-Simpson's index [101,104-106]. 
We performed indicator species analysis based on the number of individuals for all fern species in the 90 sample plots. Indicator species for different disturbance levels were obtained using the $\mathrm{R}$ package 'indicspecies' [107].

All the R codes (Codes S1 and S2) with datasets (Files S2-S4) were run with R 3.6.3 [108] in Rstudio 1.2.5033 [109].

\section{Results and Discussion}

\subsection{Sample Coverage}

Overall, we recorded a total of 4 subclasses, 9 orders, 20 families, 50 genera, and 99 species of ferns, as well as 9759 individual ferns (Table S1; Figure S1). The sample coverage curves of the ferns at three sites indicated that all sampling efforts were sufficient as they began to level off at the 26th, 19th, and 15th plot (i.e., $650 \mathrm{~m}^{2}, 475 \mathrm{~m}^{2}$, and $375 \mathrm{~m}^{2}$ ) for JLS, AJS, and LGS, respectively (Figure 2).

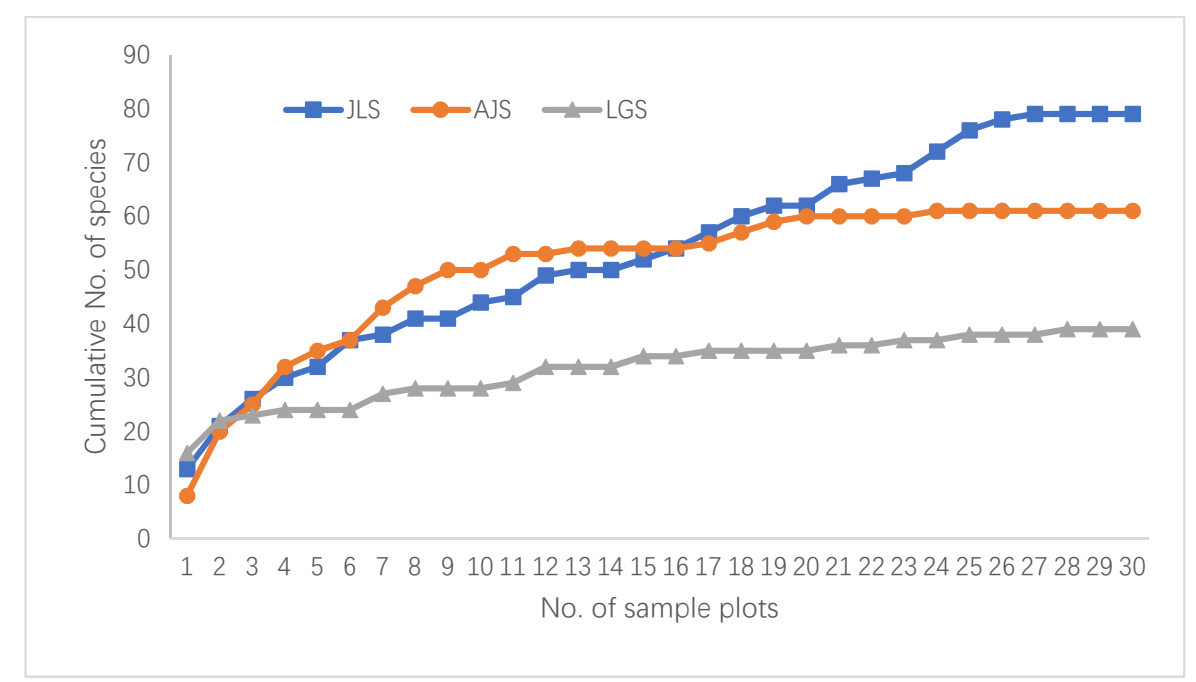

Figure 2. The sample coverage curves for ferns at three sites in Longnan County, China.

A sampling area of $600 \mathrm{~m}^{2}$ is enough for human-made forests, while $900 \mathrm{~m}^{2}$ is suggested for natural forests in the tropical regions of Malaysia and Singapore [110]. Our study sites were located in the subtropical regions, so the minimum sampling areas were smaller than those in the tropical regions. Our results also agreed that the minimum sampling areas should increase from economic to natural forests [110]. The total sampling area of $750 \mathrm{~m}^{2}$ (i.e., 30 plots) should be enough to show the relative biodiversity values at different disturbance levels.

\subsection{Taxonomic, Phylogenetic, and Functional Diversity}

On average, in each plot, we recorded 9.2 fern species, with an average of 11.0 species (range 6-19) at JLS, 7.8 (3-16) at AJS, and 8.6 (3-18) at LGS. The phylogenetic tree of all the ferns (Figure S1) showed that we recorded all four subclasses of PPG I and nine orders (Equisetales, Ophioglossales, Marattiales, Osmundales, Hymenophyllales, Gleicheniales, Schizaeales, Cyatheales, and Polypodiales, 9 of 11 from PPG I). Among the nine orders, $50 \%$ of the families and $86 \%$ of the species were from the Polypodiales, the most diverse group among the ferns.

The taxonomic diversity indicators all showed the same arrangement from higher to lower values at the three study sites: JLS > AJS > LGS, except in the abundance of individuals, which was greater at LGS (Table 3). This trend was consistent along with the increasing $q$ values of Hill numbers for all species $\left({ }^{0} T D\right.$ or species richness $\left.S\right)$, common species $\left({ }^{1} T D\right.$ or $\left.e^{H}\right)$, and dominant species $\left({ }^{2} T D\right.$ or $\left.1 / \lambda\right)$ (Figure 3a). The same pattern was found for phylogenetic diversity, including Faith's phylogenetic diversity (linked to ${ }^{0} P D$ ) and Rao's quadratic entropy (linked to ${ }^{1} P D$ ) (Figure $3 \mathrm{~b}$ ) and for functional 
diversity, including functional attribute diversity $\left(F A D\right.$ or $\left.{ }^{0} F D\right)$ and the weighted Gini-Simpson index (linked to ${ }^{2} F D$ ) (Figure 3c).

Table 3. The taxonomic diversity of ferns at three sites in Longnan County, China.

\begin{tabular}{cccc}
\hline Taxonomic Diversity Index & JLS & AJS & LGS \\
\hline Species richness $\left(S={ }^{0} T D\right)$ & $\mathbf{7 9}$ & 61 & 39 \\
Exponential of Shannon's entropy $\left(e^{H}={ }^{1} T D\right)$ & $\mathbf{5 4}$ & 39 & 21 \\
Inverse of Simpson's index $\left(1 / \lambda={ }^{2} T D\right)$ & $\mathbf{2 2}$ & 15 & 9 \\
Genus richness & $\mathbf{4 7}$ & 38 & 23 \\
Family richness & $\mathbf{2 0}$ & 17 & 11 \\
Order richness & $\mathbf{9}$ & 7 & 4 \\
Subclass richness & $\mathbf{4}$ & $\mathbf{4}$ & 1 \\
Individual number & 3250 & 2905 & $\mathbf{3 6 0 4}$ \\
\hline
\end{tabular}

${ }^{1}$ Number in bold indicating the maximum value at the three sites.
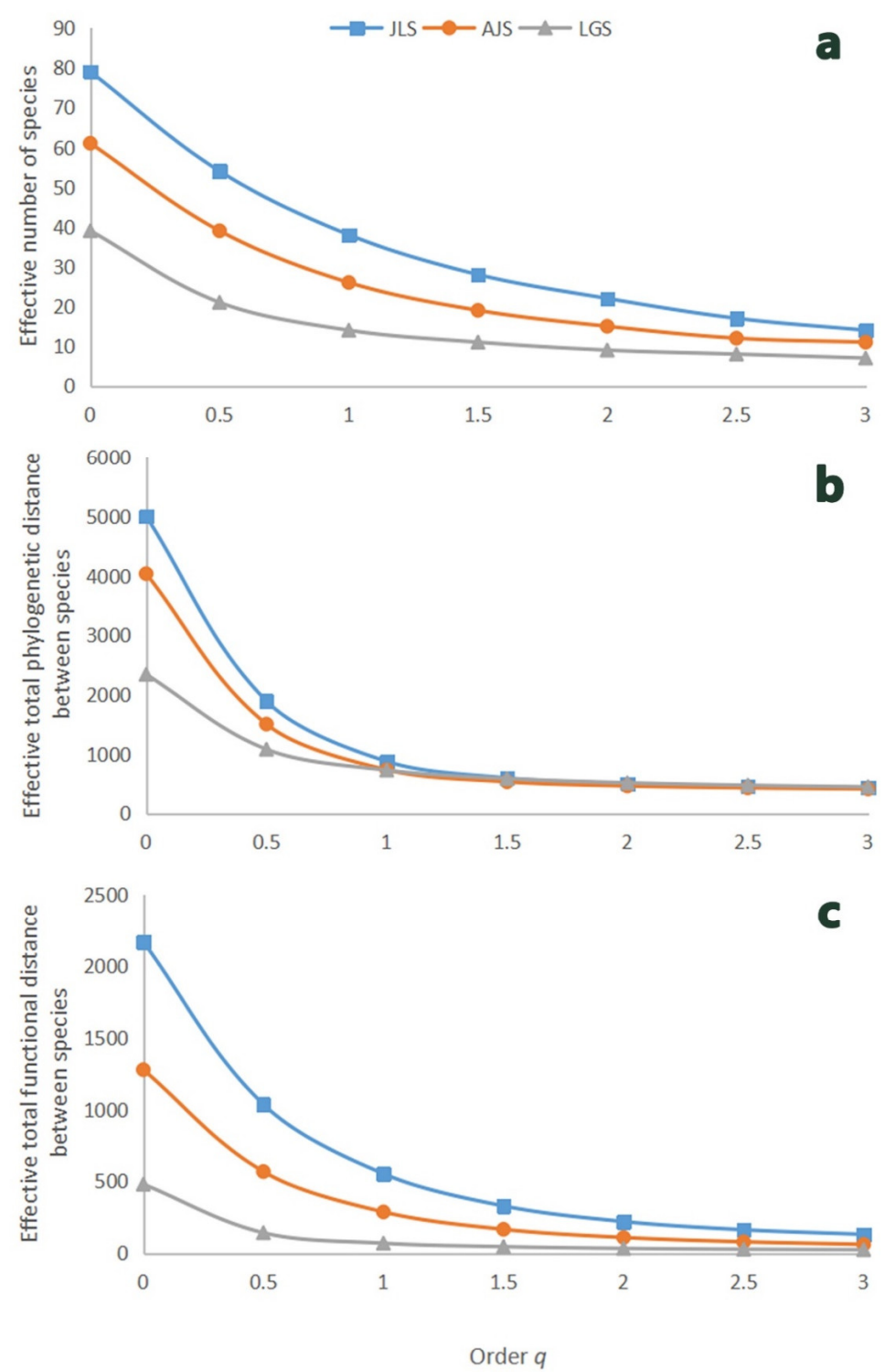

Figure 3. The Hill number-based diversity profiles of ferns at three sites in Longnan County for increasing order $q$ values (0 to 3): (a) taxonomic diversity; (b) phylogenetic diversity; and (c) functional diversity. 
The trends of the Hill number-based taxonomic, phylogenetic, and functional diversity all leveled off, and the differences between three sites became smaller (Figure 3) when the weighting of the relative abundance of each species $\left(p_{i}\right)$ increased with the increase of order $q$ (Table 2). The phylogenetic diversity among the three sites became similar when $q>1$, one possible reason might be that our phylogenetic tree was at the genus resolution rather than species resolution (Figure S1).

Hence, all three diversity components (taxonomic, phylogenetic, and functional) of fern assemblages studied here showed the same pattern of decreasing diversity with the increase of disturbance degrees, which is in accordance with the 'increasing disturbance hypothesis' $[8,55,57,65,111]$. Our sampling was conducted along roadsides, which are disturbed habitats in themselves. Thus, we are careful to interpret them in direct relation to disturbances as such, as they likely combine the effects of different degrees of disturbances at the regional level (study sites) and at the local scale (individual roadsides). A previous study in Mexico found that the functional diversity of ferns and lycophytes decreased with disturbance in species-rich habitats, but not so in species-poor habitats [12]. As our study sites were located close to each other and have similar ecological conditions, we may assume that they originally shared a similar fern flora; thus, we cannot assess the effect observed in Mexico. Clearly, the relationship of fern diversity to habitat disturbance is complex and requires further case studies.

Previous studies have found inconsistent trends among the taxonomic, phylogenetic, and functional diversity along disturbance gradients [112-115]. However, in our study, all three diversity elements consistently indicated that the biodiversity was the highest along the roadsides within the natural forests at JLS but at the lowest in the severely disturbed LGS.

Many functional traits of ferns showed differences from the species of the less altered site to those of the most disturbed site (Table 4). We found that ferns in the more strongly disturbed sites tended to have longer, narrower, and thinner laminae, and more commonly had monomorphic fronds, with sori in one row on either side of the veins, and false indusia. They also had less vegetative reproduction. At the most disturbed site of LGS, the petioles were longest, the rhizomes were all below ground, long creeping rhizomes were less common, the fronds were more strongly divided, and the scales or hairs became denser. It is tempting to interpret these trends as adaptive directly; however, it should be borne in mind that many of them show strong phylogenetic patterns, being present in some clades and not in others. Accordingly, certain traits may be overrepresented in some habitats, not because they themselves are adaptive, but rather because some other trait of a group of ferns is adaptive. Bearing these limitations in mind, some patterns deserve closer consideration. Disturbed sites have higher solar radiation and lower air humidity, which is suitable for drought-tolerant ferns but not for humidity-dependent ones [12].

Table 4. The community-level weighted means of fern trait values at the three sites in Longnan County.

\begin{tabular}{cccc}
\hline Functional Traits & JLS $\mathbf{1}^{\mathbf{1}}$ & AJS & LGS \\
\hline Lamina length & 66.048 & 68.277 & $\mathbf{8 8 . 6 7 0}$ \\
Lamina width & $\mathbf{2 1 . 3 7 3}$ & 17.624 & 17.748 \\
Petiole length & 36.720 & 33.146 & $\mathbf{4 3 . 4 8 1}$ \\
Frond heterophylly & $\mathbf{1 . 0 9 6}$ & 1.080 & 1.084 \\
Lamina texture & $\mathbf{2 . 1 7 8}$ & 2.149 & 2.087 \\
Frond arrangement & 2.066 & $\mathbf{2 . 3 8 6}$ & 2.119 \\
Rhizome type & 2.228 & $\mathbf{2 . 4 4 4}$ & 2.148 \\
Rhizome position & 1.069 & $\mathbf{1 . 0 9 4}$ & 1.000 \\
Lamina dissection & 2.617 & 2.351 & $\mathbf{3 . 1 3 1}$ \\
Lamina shape & linear-lanceolate & linear-lanceolate & linear-lanceolate \\
Sori shape & orbicular & linear & orbicular \\
Sori position & medial_on_veins & 1_row_on_either_side_of_veins & 1 1_line_on_each_side_of_costule \\
Indusia & 1.677 & 0.682 & $\mathbf{0 . 8 7 8}$ \\
Reproduction type & 1.014 & $\mathbf{1 . 0 2 3}$ & 1.002 \\
Phenology & $\mathbf{1 . 1 0 9}$ & 1.030 & $\mathbf{1 . 0 3 1}$ \\
Habit & 1.186 & 1.068 & 1.000
\end{tabular}

${ }^{1}$ Numbers in bold indicate the maximum value at three sites. 
Several of the functional traits recovered as being overrepresented in the disturbed site in our study were previously suggested to be adaptations to disturbance. Thus, in dry and hot environments, plants have narrower and pinnate leaves to allow for heat dissipation [116], and ferns show more coriaceous leaves, succulent rhizomes, denser leaf scales, and higher cell wall elasticity [15]. Rhizome type is related to space/light competition [117], frond heterophylly to spore dispersal facilitation, high lamina thickness to frost/drought adaptations, high scale and hair density to heat/water/herbivory protection, hydathodes to water transport facilitation, indusia to spore protection from water washing, and buds to wet environments [71].

\subsection{Indicator Fern Species for Different Disturbance Levels}

There were seven indicator fern species for the roadside in the strongly disturbed study sites, four for the site with an intermediate disturbance level, seven for the site with a low disturbance level, and one for the latter two sites combined (Table 5).

Table 5. Indicator fern species for different disturbance levels in Longnan County, China.

\begin{tabular}{|c|c|c|c|c|}
\hline Disturbance Level & Indicator Species & Indicator Value & $P$-Value & Significance Code ${ }^{1}$ \\
\hline \multirow{7}{*}{ High } & Dicranopteris pedata & 0.692 & 0.0001 & $* * *$ \\
\hline & Blechnum orientale & 0.612 & 0.0001 & $* * *$ \\
\hline & Odontosoria chinensis & 0.579 & 0.0001 & $* * *$ \\
\hline & Lygodium microphyllum & 0.376 & 0.0004 & $* * *$ \\
\hline & Cyclosorus parasiticus & 0.366 & 0.0015 & $* *$ \\
\hline & Christella dentata & 0.274 & 0.016 & $*$ \\
\hline & Pteris semipinnata & 0.264 & 0.0165 & * \\
\hline \multirow{4}{*}{ Intermediate } & Leptochilus hemitomus & 0.429 & 0.0001 & $* * *$ \\
\hline & Diplazium virescens & 0.331 & 0.0034 & $* *$ \\
\hline & Arachniodes chinensis & 0.330 & 0.0005 & $* * *$ \\
\hline & Coniogramme japonica & 0.248 & 0.0001 & $* * *$ \\
\hline \multirow{7}{*}{ Low } & Ctenitis subglandulosa & 0.536 & 0.0001 & $* * *$ \\
\hline & Angiopteris fokiensis & 0.434 & 0.0002 & $* * *$ \\
\hline & Cyathea hancockii & 0.378 & 0.0001 & $* * *$ \\
\hline & Cornopteris opaca & 0.333 & 0.0001 & $* * *$ \\
\hline & Dictyocline wilfordii & 0.314 & 0.0039 & $* *$ \\
\hline & Arachniodes amabilis & 0.300 & 0.0057 & $* *$ \\
\hline & Plagiogyria adnata & 0.261 & 0.0007 & $* * *$ \\
\hline Intermediate + low & Osmunda vachellii & 0.243 & 0.047 & * \\
\hline
\end{tabular}

Many fern groups, such as Gleicheniaceae, Dennstaedtiaceae, Pteridaceae, and Schizeaceae, include species that are clearly adapted to open, sunny habitats with poorly developed soils and that quickly colonize disturbed sites. Many tropical landslides are quickly colonized by Gleicheniaceae [118]. Among the seven high-disturbance indicators, previous studies found that Dicranopteris pedata and Blechnum orientale dominate the early successional stage on landslide trails [119]; Odontosoria chinensis frequently colonizes disturbed places [120]; Lygodium microphyllum has the ability to invade hurricane-disturbed areas [121]; Cyclosorus parasiticus adapts to disturbed habitats [122]; Christella dentata is common along roadsides but can also dominate in undisturbed, lightly disturbed, and moderately disturbed forests [123], which makes it a poor disturbance indicator; Pteris semipinnata is a dominant understory species in the economic needle-leaf forest of Pinus massoniana [124]. Our results are thus in accordance with the previous observations and point to a certain generality of the results obtained by us.

Among the seven low-disturbance indicators and one intermediate + low disturbance indicator: Ctenitis subglandulosa is a dominant species in the herbaceous layer in a natural evergreen forest [125]; the tree fern Cyathea hancockii is a nationally protected plant in China; and Angiopteris fokiensis and Osmunda vachellii are provincially protected plants in Jiangxi. Clearly, much less is known about these species than about the species of the highly disturbed sites, which may partly reflect that the disturbance-adapted species typically have large ranges and are common. 


\section{Conclusions}

In general, the taxonomic, phylogenetic, and functional diversity of ferns in Longnan County has been greatly influenced by human disturbances, which supports the 'increasing disturbance hypothesis'. Many functional traits of ferns have adapted accordingly to the increasing disturbance degree. We also identified some indicator fern species corresponding to different disturbance levels. Hence, ferns are an effective indicator group for environmental stress. Compared to the traditional diversity indices, Hill number-based diversity profiles provided a continuous and thorough picture of fern diversity patterns among different disturbance levels. However, the relationship of fern diversity to habitat disturbance is complex and requires further case studies. In the future, more sites should be included, and the disturbance levels should be quantified. Standard sampling protocols, molecular-based species phylogeny, and unified functional traits should also be adopted to obtain meaningful comparisons with previous publications and to obtain global-scale patterns of fern diversity.

Supplementary Materials: The following are available online at http://www.mdpi.com/1424-2818/12/4/135/s1, Code S1: Hill number-based diversity analysis.R, Code S2: Indicator species analysis.R, Figure S1: Phylogenetic tree of all fern species.tif, File S1: Phylogenetic tree of all fern species (in Newick format).txt, File S2: Fern community data ferncomm2020.txt, File S3: Fern traits data ferntraits2020.txt, File S4: Indicator species data indicatorspecies.txt, Table S1: Individual numbers of all fern species.xlsx, Table S2: Functional traits of all fern species.xlsx.

Author Contributions: Conceptualization, X.D.; methodology, X.D.; software, X.D. and C.C.; formal analysis, X.D., C.C. and Z.L.; investigation, C.C. and Z.L.; data curation, X.D., C.C. and Z.L.; writing-original draft preparation, X.D.; writing-review and editing, X.D., C.C., Z.L. and X.W.; visualization, X.D. and C.C.; supervision, X.D. and Z.L.; project administration, X.D.; funding acquisition, X.D. and Z.L. All authors have read and agreed to the published version of the manuscript.

Funding: This work was funded by the National Natural Science Foundation of China (31500169), Natural Science Foundation of Jiangxi Province (20171BAB204023) and the Jiangxi Agriculture Research System (JXARS-07).

Acknowledgments: We express our appreciation to several members of the Leafminer Group for help in field investigation and data analysis. We also thank Jiulianshan National Nature Reserve, Anjishan Provincial Forest Park, and Leigongshan Family Farm for their field assistance. Grammarly software was used for language improvement. We thank our five anonymous reviewers and the editors of Diversity for their valuable comments. We also thank MDPI for English language editing.

Conflicts of Interest: The authors declare no conflict of interest.

\section{References}

1. The Pteridophyte Phylogeny Group I. A community-derived classification for extant lycophytes and ferns. J. Syst. Evol. 2016, 54, 563-603. [CrossRef]

2. Schneider, H.; Schuettpelz, E.; Pryer, K.M.; Cranfill, R.; Magallon, S.; Lupia, R. Ferns diversified in the shadow of angiosperms. Nature 2004, 428, 553-557. [CrossRef] [PubMed]

3. Testo, W.; Sundue, M. A 4000-species dataset provides new insight into the evolution of ferns. Mol. Phylogenet. Evol. 2016, 105, 200-211. [CrossRef] [PubMed]

4. Salazar, L.; Homeier, J.; Kessler, M.; Abrahamczyk, S.; Lehnert, M.; Krömer, T.; Kluge, J. Diversity patterns of ferns along elevational gradients in Andean tropical forests. Plant Ecol. Divers. 2013, 8, 13-24. [CrossRef]

5. Chang, J.; Yoon, I.; Kim, K. Heavy metal and arsenic accumulating fern species as potential ecological indicators in As-contaminated abandoned mines. Ecol. Indic. 2009, 9, 1275-1279. [CrossRef]

6. Silva, V.L.; Mehltreter, K.; Schmitt, J.L. Ferns as potential ecological indicators of edge effects in two types of Mexican forests. Ecol. Indic. 2018, 93, 669-676. [CrossRef]

7. Bergeron, A.; Pellerin, S. Pteridophytes as indicators of urban forest integrity. Ecol. Indic. 2014, 38, 40-49. [CrossRef]

8. Abotsi, K.E.; Bose, R.; Adjossou, K.; Deblauwe, V.; Rouhan, G.; Segla, K.N.; Atsri, K.H.; Kokou, K. Ecological drivers of pteridophyte diversity and distribution in Togo (West Africa). Ecol. Indic. 2020, 108. [CrossRef]

9. Pouteau, R.; Meyer, J.Y.; Blanchard, P.; Nitta, J.H.; Terorotua, M.; Taputuarai, R. Fern species richness and abundance are indicators of climate change on high-elevation islands: Evidence from an elevational gradient on Tahiti (French Polynesia). Clim. Chang. 2016, 138, 143-156. [CrossRef] 
10. Khine, P.K.; Kluge, J.; Kessler, M.; Miehe, G.; Karger, D.N. Latitude-independent, continent-wide consistency in climate-richness relationships in Asian ferns and lycophytes. J. Biogeogr. 2019, 46, 981-991. [CrossRef]

11. Kessler, M.; Siorak, Y.; Wunderlich, M.; Wegner, C. Patterns of morphological leaf traits among pteridophytes along humidity and temperature gradients in the Bolivian Andes. Funct. Plant Biol. 2007, 34. [CrossRef]

12. Carvajal-Hernández, C.I.; Gómez-Díaz, J.A.; Kessler, M.; Krömer, T. Influence of elevation and habitat disturbance on the functional diversity of ferns and lycophytes. Plant Ecol. Divers. 2018, 11, 335-347. [CrossRef]

13. Weigand, A.; Abrahamczyk, S.; Aubin, I.; Bita-Nicolae, C.; Bruelheide, H.; Carvajal-Hernandez, C.I.; Cicuzza, D.; da Costa, L.E.N.; Csiky, J.; Dengler, J.; et al. Global fern and lycophyte richness explained: How regional and local factors shape plot richness. J. Biogeogr. 2019. [CrossRef]

14. Lwanga, J.S.; Balmford, A.; Badaza, R. Assessing fern diversity: Relative species richness and its environmental correlates in Uganda. Biodivers. Conserv. 1998, 7, 1387-1398. [CrossRef]

15. Mehltreter, K.; Walker, L.R.; Sharpe, J.M. Fern Ecology; Cambridge University Press: New York, NY, USA, 2010.

16. Hernández-Rojas, A.; Kessler, M.; Krömer, T.; Carvajal-Hernández, C.; Weigand, A.; Kluge, J. Richness patterns of ferns along an elevational gradient in the Sierra de Juárez, Oaxaca, Mexico: A comparison with Central and South America. Am. Fern J. 2018, 108, 76-94. [CrossRef]

17. Grytnes, J.A.; Beaman, J.H. Elevational species richness patterns for vascular plants on Mount Kinabalu, Borneo. J. Biogeogr. 2006, 33, 1838-1849. [CrossRef]

18. Luna-Vega, I.; Tejero-Diez, J.D.; Contreras-Medina, R.; Heads, M.; Rivas, G. Biogeographical analysis of two Polypodium species complexes (Polypodiaceae) in Mexico and Central America. Biol. J. Linn. Soc. 2012, 106, 940-955. [CrossRef]

19. Tanaka, T.; Sato, T. Elevational patterns of fern species assemblages and richness in central Japan. Plant Ecol. 2013, 214, 1189-1197. [CrossRef]

20. Hemp, A. Ecology of the pteridophytes on the southern slopes of Mt. Kilimanjaro, I. Altitudinal distribution. Plant Ecol. 2002, 159, 211-239. [CrossRef]

21. Kessler, M.; Kluge, J.; Hemp, A.; Ohlemuller, R. A global comparative analysis of elevational species richness patterns of ferns. Glob. Ecol. Biogeogr. 2011, 20, 868-880. [CrossRef]

22. Watkins, J.E., Jr.; Cardelus, C.; Colwell, R.K.; Moran, R.C. Species richness and distribution of ferns along an elevational gradient in Costa Rica. Am. J. Bot. 2006, 93, 73-83. [CrossRef]

23. Jácome, J.; Kessler, M.; Smith, A.R. A human-induced downward-skewed elevational abundance distribution of pteridophytes in the Bolivian Andes. Glob. Ecol. Biogeogr. 2007, 16, 313-318. [CrossRef]

24. Parra, M.J.; Rodriguez, R.; Cavieres, L.; Munoz-Tapia, L.; Atala, C. Latitudinal patterns in Pteridophyte distribution of Continental Chile. Gayana Bot. 2015, 72, 58-69. [CrossRef]

25. Wei, R.; Ree, R.H.; Sundue, M.A.; Zhang, X. Polyploidy and elevation contribute to opposing latitudinal gradients in diversification and species richness in lady ferns (Athyriaceae). BioRxiv 2018. [CrossRef]

26. Karger, D.N.; Kluge, J.; Kromer, T.; Hemp, A.; Lehnert, M.; Kessler, M. The effect of area on local and regional elevational patterns of species richness. J. Biogeogr. 2011, 38, 1177-1185. [CrossRef]

27. Bhattarai, K.R.; Vetaas, O.R.; Grytnes, J.A. Fern species richness along a central Himalayan elevational gradient, Nepal. J. Biogeogr. 2004, 31, 389-400. [CrossRef]

28. Kluge, J.; Kessler, M. Fern endemism and its correlates: Contribution from an elevational transect in Costa Rica. Divers. Distrib. 2006, 12, 535-545. [CrossRef]

29. Syfert, M.M.; Brummitt, N.A.; Coomes, D.A.; Bystriakova, N.; Smith, M.J. Inferring diversity patterns along an elevation gradient from stacked SDMs: A case study on Mesoamerican ferns. Glob. Ecol. Conserv. 2018, 16. [CrossRef]

30. Kluge, J.; Kessler, M. Influence of niche characteristics and forest type on fern species richness, abundance and plant size along an elevational gradient in Costa Rica. Plant Ecol. 2011, 212, 1109-1121. [CrossRef]

31. Karst, J.; Gilbert, B.; Lechowicz, J. Fern community assembly: The roles of chance and the environment at local and intermediate scales. Ecology 2005, 96, 2473-2486. [CrossRef]

32. Qian, H.; Wang, S.; Li, Y.; Xiao, M.; Wang, X. Disentangling the relative effects of ambient energy, water availability, and energy-water balance on pteridophyte species richness at a landscape scale in China. Plant Ecol. 2012, 213, 749-756. [CrossRef] 
33. Nagalingum, N.S.; Knerr, N.; Laffan, S.W.; Gonzalez-Orozco, C.E.; Thornhill, A.H.; Miller, J.T.; Mishler, B.D. Continental scale patterns and predictors of fern richness and phylogenetic diversity. Front. Genet. 2015, 6, 132. [CrossRef]

34. Kluge, J.; Bach, K.; Kessler, M. Elevational distribution and zonation of tropical pteridophyte assemblages in Costa Rica. Basic Appl. Ecol. 2008, 9, 35-43. [CrossRef]

35. Acebey, A.R.; Kromer, T.; Kessler, M. Species richness and vertical distribution of ferns and lycophytes along an elevational gradient in Los Tuxtlas, Veracruz, Mexico. Flora 2017, 235, 83-91. [CrossRef]

36. Kluge, J.; Kessler, M.; Dunn, R.R. What drives elevational patterns of diversity? A test of geometric constraints, climate and species pool effects for pteridophytes on an elevational gradient in Costa Rica. Glob. Ecol. Biogeogr. 2006, 15, 358-371. [CrossRef]

37. Zhang, Q.; Wang, Z.; Ji, M.; Fan, Z.; Deng, J. Patterns of species richness in relation to temperature, taxonomy and spatial scale in eastern China. Acta Oecologica Int. J. Ecol. 2011, 37, 307-313. [CrossRef]

38. Marini, L.; Bona, E.; Kunin, W.E.; Gaston, K.J. Exploring anthropogenic and natural processes shaping fern species richness along elevational gradients. J. Biogeogr. 2011, 38, 78-88. [CrossRef]

39. Nervo, M.H.; Andrade, B.O.; Tornquist, C.G.; Mazurana, M.; Windisch, P.G.; Overbeck, G.E. Distinct responses of terrestrial and epiphytic ferns and lycophytes along an elevational gradient in Southern Brazil. J. Veg. Sci. 2019, 30, 55-64. [CrossRef]

40. Tanaka, T.; Sato, T. Species richness of seed plants and ferns along a temperate elevational gradient in central Japan. Plant Ecol. 2014, 215, 1299-1311. [CrossRef]

41. Schneider, H.; He, L.; Marquardt, J.; Wang, L.; Heinrichs, J.; Hennequin, S.; Zhang, X. Exploring the origin of the latitudinal diversity gradient: Contrasting the sister fern genera Phegopteris and Pseudophegopteris. J. Syst. Evol. 2013, 51, 61-70. [CrossRef]

42. Zhang, H.; Zhu, S.; John, R.; Li, R.; Liu, H.; Ye, Q. Habitat filtering and exclusion of weak competitors jointly explain fern species assemblage along a light and water gradient. Sci. Rep. 2017, 7, 298. [CrossRef]

43. Creese, C.; Lee, A.; Sack, L. Drivers of morphological diversity and distribution in the Hawaiian fern flora: Trait associations with size, growth form, and environment. Am. J. Bot. 2011, 98, 956-966. [CrossRef]

44. Kessler, M.; Gudel, R.; Salazar, L.; Homeier, J.; Kluge, J. Impact of mycorrhization on the abundance, growth and leaf nutrient status of ferns along a tropical elevational gradient. Oecologia 2014, 175, 887-900. [CrossRef]

45. Hietz, P.; Briones, O. Correlation between water relations and within-canopy distribution of epiphytic ferns in a Mexican cloud forest. Oecologia 1998, 114, 305-316. [CrossRef]

46. Paixão, E.C.; Noronha, J.d.C.d.; Nunes da Cunha, C.; Arruda, R. More than light: Distance-dependent variation on riparian fern community in Southern Amazonia. Braz. J. Bot. 2013, 36, 25-30. [CrossRef]

47. Zuquim, G.; Tuomisto, H.; Jones, M.M.; Prado, J.; Figueiredo, F.O.G.; Moulatlet, G.M.; Costa, F.R.C.; Quesada, C.A.; Emilio, T.; Rocchini, D. Predicting environmental gradients with fern species composition in Brazilian Amazonia. J. Veg. Sci. 2014, 25, 1195-1207. [CrossRef]

48. Jones, M.M.; Cicuzza, D.; van Straaten, O.; Veldkamp, E.; Kessler, M.; Pugnaire, F. Determinants of fern and angiosperm herb community structure in lower montane rainforest in Indonesia. J. Veg. Sci. 2014, 25, 1216-1224. [CrossRef]

49. Zhang, L.; Wang, X.; Liu, J.; Zhan, X. The relationship between biodiversity and canopy openness of tropical ground ferns under three different forest types. China For. Sci. Technol. 2015, 29, $23-27$.

50. Kessler, M.; Lehnert, M. Do ridge habitats contribute to pteridophyte diversity in tropical montane forests? A case study from southeastern Ecuador. J. Plant Res. 2009, 122, 421-428. [CrossRef]

51. Yan, Y.; He, Z.; Yuan, H.; Xing, F. The ecological response of fern diversity to different slopes in Gudoushan Nature Reserve, Guangdong. Biodivers. Sci. 2011, 19, 41-47.

52. Nettesheim, F.C.; Damasceno, E.R.; Sylvestre, L.S. Different slopes of a mountain can determine the structure of ferns and lycophytes communities in a tropical forest of Brazil. An. Acad. Bras. Cienc. 2014, 86, 199-210. [CrossRef]

53. Xu, C.; Li, X.; Feng, J. Relationships between epiphyte ferns species diversity and their phorophytes in Mt. Ailao National Nature Reserve. Chin. J. Ecol. 2011, 30, 1858-1862.

54. Ceballos, G.; Ehrlich, P.R.; Barnosky, A.D.; Garcia, A.; Pringle, R.M.; Palmer, T.M. Accelerated modern human-induced species losses: Entering the sixth mass extinction. Sci. Adv. 2015, 1, e1400253. [CrossRef] [PubMed] 
55. Oldekop, J.A.; Bebbington, A.J.; Truelove, N.K.; Tysklind, N.; Villamarin, S.; Preziosi, R.F. Co-occurrence patterns of common and rare leaf-litter frogs, epiphytic ferns and dung beetles across a gradient of human disturbance. PLoS ONE 2012, 7, e38922. [CrossRef] [PubMed]

56. Bystriakova, N.; Bader, M.; Coomes, D.A. Long-term tree fern dynamics linked to disturbance and shade tolerance. J. Veg. Sci. 2011, 22, 72-84. [CrossRef]

57. Carvajal-Hernández, C.I.; Krömer, T.; López-Acosta, J.C.; Gómez-Díaz, J.A.; Kessler, M.; Wulf, M. Conservation value of disturbed and secondary forests for ferns and lycophytes along an elevational gradient in Mexico. Appl. Veg. Sci. 2017, 20, 662-672. [CrossRef]

58. Rodríguez, M.R.; Zavala, J.H.; Pacheco, L. Presence, abundance and reproductive strategies of ferns in disturbed areas of Sierra Nevada, México. Rev. Biol. Trop. 2011, 59, 417-433.

59. Castello, A.C.D.; Coelho, S.; Cardoso-Leite, E. Lianas, tree ferns and understory species: Indicators of conservation status in the Brazilian Atlantic Rainforest remnants, southeastern Brazil. Braz. J. Biol. 2017, 77, 213-226. [CrossRef]

60. Silva, I.A.A.; Pereira, A.F.N.; Barros, I.C.L. Edge effects on fern community in an Atlantic forest remnant of Rio Formoso, PE, Brazil. Braz. J. Biol. 2011, 71, 421-430. [CrossRef]

61. Kessler, M. Plant species richness and endemism during natural landslide succession in a perhumid montane forest in the Bolivian Andes. Ecotropica 1999, 5, 123-136.

62. Kessler, M. Maximum plant community endemism at intermediate intensities of anthropogenic disturbance in Bolivian montane forests. Conserv. Biol. 2001, 15, 634-641. [CrossRef]

63. Blair, D.P.; McBurney, L.M.; Blanchard, W.; Banks, S.C.; Lindenmayer, D.B. Disturbance gradient shows logging affects plant functional groups more than fire. Ecol. Appl. 2016, 26, 2280-2301. [CrossRef] [PubMed]

64. Ough, K.; Murphy, A. Decline in tree-fern abundance after clearfell harvesting. For. Ecol. Manag. 2004, 199, 153-163. [CrossRef]

65. Paciencia, M.L.B.; Prado, J. Effects of forest fragmentation on pteridophyte diversity in a tropical rain forest in Brazil. Plant Ecol. 2005, 180, 87-104. [CrossRef]

66. da Silva, I.A.A.; Pereira, A.F.D.N.; Barros, I.C.L. Fragmentation and loss of habitat: Consequences for the fern communities in Atlantic forest remnants in Alagoas, north-eastern Brazil. Plant Ecol. Divers. 2014, 7, 509-517. [CrossRef]

67. Connell, J.H. Diversity in tropical rain forests and coral reefs. Science 1978, 199, 1302-1310. [CrossRef]

68. Gray, J.S. Effects of environmental stress on species rich assemblages. Biol. J. Linn. Soc. 1989, 37, 19-32. [CrossRef]

69. Magura, T.; Tothmeresz, B.; Molnar, T. Changes in carabid beetle assemblages along an urbanisation gradient in the city of Debrecen, Hungary. Landsc. Ecol. 2004, 19, 747-759. [CrossRef]

70. Tanaka, T.; Sato, T. Taxonomic, phylogenetic and functional diversities of ferns and lycophytes along an elevational gradient depend on taxonomic scales. Plant Ecol. 2015, 216, 1597-1609. [CrossRef]

71. Kluge, J.; Kessler, M. Phylogenetic diversity, trait diversity and niches: Species assembly of ferns along a tropical elevational gradient. J. Biogeogr. 2011, 38, 394-405. [CrossRef]

72. Hill, M.O. Diversity and evenness: A unifying notation and its consequences. Ecology 1973, 54, 427-432. [CrossRef]

73. Chao, A.; Chiu, C.; Jost, L. Phylogenetic diversity measures based on Hill numbers. Philos. Trans. R. Soc. Lond. B Biol. Sci. 2010, 365, 3599-3609. [CrossRef]

74. Chao, A.; Gotelli, N.J.; Hsieh, T.; Sander, E.L.; Ma, K.; Colwell, R.K.; Ellison, A.M. Rarefaction and extrapolation with Hill numbers: A framework for sampling and estimation in species diversity studies. Ecol. Monogr. 2014, 84, 45-67. [CrossRef]

75. Hsieh, T.; Ma, K.; Chao, A. iNEXT: An R package for rarefaction and extrapolation of species diversity (Hill numbers). Methods Ecol. Evol. 2016, 7, 1451-1456. [CrossRef]

76. Hsieh, T.; Chao, A. Rarefaction and extrapolation: Making fair comparison of abundance-sensitive phylogenetic diversity among multiple assemblages. Syst. Biol. 2017, 66, 100-111. [CrossRef]

77. Chao, A.; Chiu, C.; Jost, L. Unifying species diversity, phylogenetic diversity, functional diversity, and related similarity and differentiation measures through Hill numbers. Annu. Rev. Ecol. Evol. Syst. 2014, 45, $297-324$. [CrossRef]

78. Vega-Álvarez, J.; García-Rodríguez, J.A.; Cayuela, L.; Swenson, N. Facilitation beyond species richness. J. Ecol. 2019, 107, 722-734. [CrossRef] 
79. Ebihara, A.; Nitta, J.H. An update and reassessment of fern and lycophyte diversity data in the Japanese Archipelago. J. Plant Res. 2019, 132, 723-738. [CrossRef]

80. Sessa, E.B.; Chambers, S.M.; Li, D.; Trotta, L.; Endara, L.; Burleigh, J.G.; Baiser, B. Community assembly of the ferns of Florida. Am. J. Bot. 2018, 105, 549-564. [CrossRef] [PubMed]

81. Link-Pérez, M.A.; Laffan, S.W. Fern and lycophyte diversity in the Pacific Northwest: Patterns and predictors. J. Syst. Evol. 2018, 56, 498-522. [CrossRef]

82. Lehtonen, S.; Jones, M.M.; Zuquim, G.; Prado, J.; Tuomisto, H. Phylogenetic relatedness within Neotropical fern communities increases with soil fertility. Glob. Ecol. Biogeogr. 2015, 24, 695-705. [CrossRef]

83. Kessler, M.; Karger, D.N.; Kluge, J. Elevational diversity patterns as an example for evolutionary and ecological dynamics in ferns and lycophytes. J. Syst. Evol. 2016, 54, 617-625. [CrossRef]

84. The Editorial Committee of China National Geographic Atlas. China National Geographic Atlas; Encyclopedia of China Publishing House: Beijing, China, 2011.

85. Steinshouer, D.W.; Qiang, J.; McCabe, P.J.; Ryder, R.T. Maps Showing Geology, Oil and Gas Fields, and Geologic Provinces of the Asia Pacific Region; 97-470F; USGA: Reston, VA, USA, 1999.

86. Liu, P.; Liao, C.; Xu, J.; Staines, C.L.; Dai, X. The Cassidinae beetles of Longnan County (Jiangxi, China): Overview and community composition. Biodivers. Data J. 2019, 7, e39053. [CrossRef]

87. Dai, X.; Xu, J.; Guo, Q.; Lai, S.; Liu, P.; Fan, J.; Tang, P. Density effect and intraspecific competition in a leaf-mining moth on bamboo leaves. J. For. Res. 2018, 30, 689-697. [CrossRef]

88. Dai, X.; Xu, J.; Ding, X. Circular distribution pattern of plant modulars and endophagous herbivory within tree crowns: The impact of roadside light conditions. J. Insect Sci. 2013, 13, 141. [CrossRef]

89. Dai, X.; Xu, J.; Cai, L. Effects of roads on Castanopsis carlesii seedlings and their leaf herbivory in a subtropical forest in China. J. Insect Sci. 2014, 14, 17. [CrossRef]

90. QGIS Development Team. QGIS Geographic Information System; Open Source Geospatial Foundation Project. Available online: http://qgis.osgeo.org (accessed on 4 February 2020).

91. Yan, Y.; Yi, Q.; Huang, Z.; Xing, F. The ecological response of fern diversity to vegetation succession in Gudoushan Nature Reserve, Guangdong. Biodivers. Sci. 2004, 12, 339-347.

92. Bystriakova, N.; Peregrym, M.; Dragicevic, S. Effect of environment on distributions of rock ferns in the Mediterranean climate: The case of the genus Asplenium in Montenegro. Flora Morphol. Distrib. Funct. Ecol. Plants 2015, 215, 84-91. [CrossRef]

93. Pryer, K.M.; Schneider, H.; Smith, A.R.; Cranfill, R.; Wolf, P.G.; Hunt, J.S.; Sipes, S.D. Horsetails and ferns are a monophyletic group and the closest living relatives to seed plants. Nature 2001, 409, 618-622. [CrossRef]

94. Zhang, J. Plantlist: Looking up the Status of Plant Scientific Names Based on the Plant List Database. R Package Version 0.5. 5. Available online: https://github.com/helixcn/plantlist (accessed on 15 November 2018).

95. Jin, Y.; Qian, H.V. PhyloMaker: An R package that can generate very large phylogenies for vascular plants. Ecography 2019, 42, 1353-1359. [CrossRef]

96. Zanne, A.E.; Tank, D.C.; Cornwell, W.K.; Eastman, J.M.; Smith, S.A.; FitzJohn, R.G.; McGlinn, D.J.; O'Meara, B.C.; Moles, A.T.; Reich, P.B.; et al. Three keys to the radiation of angiosperms into freezing environments. Nature 2014, 506, 89-92. [CrossRef]

97. Smith, S.A.; Brown, J.W. Constructing a broadly inclusive seed plant phylogeny. Am. J. Bot. 2018, 105, 302-314. [CrossRef]

98. Kembel, S.W.; Cowan, P.D.; Helmus, M.R.; Cornwell, W.K.; Morlon, H.; Ackerly, D.D.; Blomberg, S.P.; Webb, C.O. Picante: R tools for integrating phylogenies and ecology. Bioinformatics 2010, 26, 1463-1464. [CrossRef]

99. Laliberte, E.; Legendre, P. A distance-based framework for measuring functional diversity from multiple traits. Ecology 2010, 91, 299-305. [CrossRef]

100. Li, D. hillR: Taxonomic, functional, and phylogenetic diversity and similarity through Hill Numbers. J. Open Source Softw. 2018, 3, 1041. [CrossRef]

101. Chiu, C.; Chao, A. Distance-based functional diversity measures and their decomposition: A framework based on Hill numbers. PLoS ONE 2014, 9, e100014. [CrossRef]

102. Morris, E.K.; Caruso, T.; Buscot, F.; Fischer, M.; Hancock, C.; Maier, T.S.; Meiners, T.; Muller, C.; Obermaier, E.; Prati, D.; et al. Choosing and using diversity indices: Insights for ecological applications from the German Biodiversity Exploratories. Ecol. Evol. 2014, 4, 3514-3524. [CrossRef]

103. Faith, D.P. Conservation evaluation and phylogenetic diversity. Biol. Conserv. 1992, 61, 1-10. [CrossRef] 
104. Walker, B.; Kinzig, A.; Langridge, J. Plant attribute diversity, resilience, and ecosystem function: The nature and significance of dominant and minor species. Ecosystems 1999, 2, 95-113. [CrossRef]

105. Guiasu, R.C.; Guiasu, S. The weighted quadratic index of biodiversity for pairs of species: A generalization of Rao's index. Nat. Sci. 2011, 3, 795-801. [CrossRef]

106. Guiasu, R.C.; Guiasu, S. The weighted Gini-Simpson index: Revitalizing an old index of biodiversity. Int. J. Ecol. 2012, 2012, 1-10. [CrossRef]

107. Caceres, M.D.; Legendre, P. Associations between species and groups of sites: Indices and statistical inference. Ecology 2009, 90, 3566-3574. [CrossRef]

108. R Core Team. R: A Language and Environment for Statistical Computing; R Foundation for Statistical Computing: Vienna, Austria, 2019.

109. RStudio Team. RStudio: Integrated Development for R; RStudio, Inc.: Boston, MA, USA, 2019.

110. Yusuf, F.B.; Tan, B.C.; Turner, I.M. What is the minimum area needed to estimate the biodiversity of pteridophytes in natural and man-made lowland forests in Malaysia and Singapore? Fern Gaz. 2003, 17, 1-9.

111. Barthlott, W.; Schmit-Neuerburg, V.; Nieder, J.; Engwald, S. Diversity and abundance of vascular epiphytes: A comparison of secondary vegetation and primary montane rain forest in the Venezuelan Andes. Plant Ecol. 2001, 152, 145-156. [CrossRef]

112. De Palma, A.; Kuhlmann, M.; Bugter, R.; Ferrier, S.; Hoskins, A.J.; Potts, S.G.; Roberts, S.P.M.; Schweiger, O.; Purvis, A. Dimensions of biodiversity loss: Spatial mismatch in land-use impacts on species, functional and phylogenetic diversity of European bees. Divers. Distrib. 2017, 23, 1435-1446. [CrossRef]

113. Giehl, E.L.H.; Jarenkow, J.A.; Prinzing, A. Disturbance and stress gradients result in distinct taxonomic, functional and phylogenetic diversity patterns in a subtropical riparian tree community. J. Veg. Sci. 2015, 26, 889-901. [CrossRef]

114. Marchant, R. The use of taxonomic distinctness to assess environmental disturbance of insect communities from running water. Freshw. Biol. 2007, 52, 1634-1645. [CrossRef]

115. Sobral, F.L.; Jardim, L.; Lemes, P.; Machado, N.; Loyola, R.; Cianciaruso, M.V. Spatial conservation priorities for top predators reveal mismatches among taxonomic, phylogenetic and functional diversity. Nat. Conserv. 2014, 12, 150-155. [CrossRef]

116. Li, Y.; Lu, Q.; Wu, B.; Zhu, Y.; Liu, D.; Zhang, J.; Jin, Z. A review of leaf morphology plasticity linked to plant response and adaptation characteristics in arid ecosystems. Chin. J. Plant Ecol. 2012, 36, 88-98. [CrossRef]

117. Kluge, J.; Kessler, M. Morphological characteristics of fern assemblages along an elevational gradient: Patterns and causes. Ecotropica 2007, 13, 27-43.

118. Gonzales, J.; Kessler, M. A synopsis of the Neotropical species of Sticherus (Gleicheniaceae), with descriptions of nine new species. Phytotaxa 2011, 31, 1-54.

119. Pang, C.; Ma, X.K.; Hung, T.T.; Hau, B.C. Early ecological succession on landslide trails, Hong Kong, China. Ecoscience 2018, 25, 153-161. [CrossRef]

120. Ranker, T.A.; Gemmill, C.E.C.; Trapp, P.G. Microevolutionary patterns and processes of the native Hawaiian colonizing fern Odontosoria chinensis (Lindsaeaceae). Evolution 2000, 54, 828-839. [CrossRef]

121. Lynch, R.L.; Chen, H.; Brandt, L.A.; Mazzotti, F.J. Old World climbing fern (Lygodium microphyllum) invasion in hurricane caused treefalls. Nat. Areas J. 2009, 29, 210-215. [CrossRef]

122. Hou, X.; Liu, S.; Zhao, S.; Beazley, R.; Cheng, F.; Wu, X.; Xu, J.; Dong, S. Selection of suitable species as a key factor for vegetation restoration of degraded areas in an open-pit manganese-ore mine in Southern China using multivariate-analysis methods. Land Degrad. Dev. 2019, 30, 942-950. [CrossRef]

123. Ramadhanil, R.; Tjitrosoedirdjo, S.S.; Setiadi, D. Structure and composition of understory plant assemblages of six land use types in the Lore Lindu National Park, Central Sulawesi, Indonesia. Bangladesh J. Plant Taxon. 2008, 15, 1-12. [CrossRef]

124. Kang, B.; Liu, S.; Cai, D.; Lu, L. Effects of Pinus massoniana plantation stand density on understory vegetation and soil properties. Chin. J. Appl. Ecol. 2009, 20, 2323-2331.

125. He, J.; Chen, W.; Xie, Z.; Hu, D. Types of the evergreen broadleaf forest and their community species diversity in Longqishan Nature Reserve, Fujian Province. Chin. J. Ecol. 1998, 17, 1-6.

(C) 2020 by the authors. Licensee MDPI, Basel, Switzerland. This article is an open access article distributed under the terms and conditions of the Creative Commons Attribution (CC BY) license (http://creativecommons.org/licenses/by/4.0/). 